\title{
Images of Reach, Range, and Recognition: Thinking about emotions in the study of international law
}

Emily Kidd White

Osgoode Hall Law School of York University, ekwhite@osgoode.yorku.ca

Source Publication:

Edward Elgar Research Handbook on Law and Emotion

Follow this and additional works at: https://digitalcommons.osgoode.yorku.ca/scholarly_works

Part of the Law and Philosophy Commons, Law and Psychology Commons, and the Rule of Law Commons

\section{Repository Citation}

Kidd White, Emily, "Images of Reach, Range, and Recognition: Thinking about emotions in the study of international law" (2021). Articles \& Book Chapters. 2830.

https://digitalcommons.osgoode.yorku.ca/scholarly_works/2830

This Book Chapter is brought to you for free and open access by the Faculty Scholarship at Osgoode Digital Commons. It has been accepted for inclusion in Articles \& Book Chapters by an authorized administrator of Osgoode Digital Commons. 
Images of Reach, Range, and Recognition: Thinking about emotions in the study of international law

\author{
Emily Kidd White*
}

Not a final version - forthcoming in the Edward Elgar Research Handbook on Law and Emotion, Susan A. Bandes, Jody Lynee Madeira, Kathryn Temple and Emily Kidd White eds. 2021.

\footnotetext{
*Assistant Professor, Osgoode Law School. Contact: ekwhite@osgoode.yorku.ca
} 


\begin{abstract}
:
There is much critical potential in bringing together the philosophy of emotion and the study of international law. Narratives about legitimate political and legal authority have tended to either assume that it is possible to extricate emotions from political judgement, or to rest upon uncomplicated (and wholly demystified) assumptions about the legibility of emotions over time and place. Philosophers interested in emotion have regularly grappled with questions concerning an emotion's reach and range (insofar that the emotion in question bears an intersubjective component), and recognition (comprehensibility) of emotions beyond one's own social and political communities (or even beyond one's self). Emotions contain evaluative judgments, and, as such, they strike as subjectively involved and image-laden "engagements with the world" (to quote Robert Solomon's memorable phrase). Where evaluative judgements are embedded within the structure of an emotion, we can expect it to be scripted, at least to an extent, by time and place, which raises, in turn, questions of all sorts pertaining to reach, range, and recognition.
\end{abstract}

Keywords: philosophy of emotion, law and emotion, international law, legal philosophy 
"A favourite nineteenth-century way of getting a man to buy a chair was to call it sincere..."

Randall Jarrell reviewing Russell Lynes's The Tastemakers, "Very Graceful Are the Uses of Culture", Harpers (1954).

There is much critical potential in bringing together the philosophy of emotion and the study of international law. ${ }^{1}$ Narratives about legitimate political and legal authority have tended to either assume that it is possible to extricate emotions from political judgement, or to rest upon uncomplicated (and wholly demystified) assumptions about the legibility of emotions over time and place. David Hume in Book III of $A$ Treatise of Human Nature declared there "is no such passion in human minds, as the love of mankind". ${ }^{2}$ For Hume, sympathy was stirred by particularities, and proximity to pain. Such an abstract, and general category as "mankind" lacked firm associations and was therefore impossible to grip. Like Hume, philosophers interested in emotion have regularly grappled with questions concerning an emotion's reach and range, and so too, our ability to recognize the emotions of others (or even those belonging to the self), including the emotions of others outside one's own social and political spheres. While some psychologists and biologists have suggested a certain universal structure for at least a few 'core' emotions, ${ }^{3}$ many, if not all, emotions contain evaluative judgments, ${ }^{4}$ and, as such, they strike as subjectively-involved and image-laden "engagements with the world" (to quote Robert Solomon's memorable phrase). ${ }^{5}$ Where evaluative judgements are embedded within the structure

1 An early version of this paper was presented at a panel on "Emotions and International Law" organized Rebecca Sutton and Anne Saab at the 2018 Law and Society Association Annual Meeting in Washington, D.C. The panel represented the first meeting of the Law and Emotions $C R N$ and the International Law and Politics CRN. An unforgettable set of papers were delivered by my co-panelists Rebecca Sutton, Anne Saab, Irene Claeys, Ioannis Kalpouzos, and Itamar Mann on the subject. I thank them for this time together.

2 David Hume, Stuart D. Warner, and Donald W. Livingston, Political Writings (Indianapolis: Hackett Pub. Co, 1994).

3 Charles Darwin and Paul Ekman, The Expression of the Emotions in Man and Animals (London: HarperCollins, 1998); Paul Ekman and Richard J. Davidson, eds., The Nature of Emotion: Fundamental Questions (New York: Oxford University Press, 1994).

${ }_{4}$ Martha Craven Nussbaum, Upheavals of Thought: The Intelligence of Emotions, 8th pr (Cambridge: Cambridge Univ. Press, 2008); Ronald De Sousa, The Rationality of Emotion, Books (Cambridge, Mass.: MIT Press, 1997); Robert C. Solomon, Not Passion's Slave: Emotions and Choice (Oxford; New York: Oxford University Press, 2003); Jenefer Robinson, Deeper than Reason: Emotion and Its Role in Literature, Music, and Art (Oxford: New York: Clarendon Press; Oxford University Press, 2005).

5 Robert C. Solomon, The Passions: Emotions and the Meaning of Life (Ind: Hackett Pub. 1993). 
of an emotion, we can expect it to be scripted, at least to an extent, by time and place, which raises, in turn, questions of all sorts pertaining to reach, range, and recognition.

Talk of emotions tends to remind us about bodies (and the persons, lands, and objects with which they are consciously and subconsciously attuned), and, at times, as Hume has just done, the absurdity, or strangeness at the very least, of highly abstract concepts that appear to do work in the field of international law. The aim of this chapter is to begin mapping a series of images regarding distance, and range within the analytical philosophical literature on emotion to see what questions they might press on the theories and practices of international law, and on the authority of international law.

To begin in broad register, we might say that the study of international or transnational law brings to the fore, amongst other things, questions of politics, power, distribution, contingency, treaties, ownership, and jurisdiction. ${ }^{6}$ Emotions bring to the study of law questions of perception, consciousness, intensity, truthfulness, bodies, precarity, relations, desires, and objects. ${ }^{7}$ Both raise questions of time, place, boundaries, and political authority. Pervasive in both disciplines are difficult questions concerning the identification and definition of the object of study (and the distance or time horizon with which to best access or understand that object) ${ }^{8}$, which, in turn, raise questions about one's research methods and aims.

6 James Crawford, Martti Koskenniemi, and Surabi Ranganathan, The Cambridge Companion to International Law (Cambridge: Cambridge University Press, 2015); James Crawford, Brownlie's Principles of Public International Law (New York, NY: Oxford University Press, 2019); Jochen Von Bernstorff, The Battle for International Law: South-North Perspectives on the Decolonization Era (New York, NY: Oxford University Press, 2019); Shaunnagh Dorsett and Shaun McVeigh, Jurisdiction (Milton Park, Abingdon, Oxon; New York, NY: Routledge, 2012).

Emily Kidd White, "On Emotions and the Politics of Attention in Judicial Reasoning," in Virtue, Emotion and Imagination in Legal Reasoning, ed. Amalia Amaya and Maksymilian Del Mar (London; UK: Hart Publishing, 2020); Emily Kidd White, Emotions in Legal Reasoning, Oxford Legal Philosophy (Oxford University Press, forthcoming); Susan A. Bandes, ed., The Passions of Law, Critical America (New York: New York University Press, 1999); John Deigh, Emotions, Values, and the Law (Oxford; New York: Oxford University Press, 2008); Amalia Amaya and Maksymilian Del Mar, eds., Virtue, Emotion, and Imagination in Law and Legal Reasoning (Chicago: Hart Publishing, 2020); Martha Craven Nussbaum, Hiding from Humanity: Disgust, Shame, and the Law (Princeton, N.J: Princeton University Press, 2004).

8 Peter Goldie, "Narrative Thinking, Emotion, and Planning," The Journal of Aesthetics and Art Criticism 67, no. 1 (2009): 97(10). 
There are several, but at least four, scripts that provide different sorts of reasons for studying emotions in the territories of international law. These are sketched below, though strict boundaries between them are not intended. In many cases, metaphysical, epistemological, and political commitments undergird and bridge these pieces in various ways.

\section{Part I: Four Scripts for Studying Emotions in International Law}

\section{Law on the Ground}

The study of emotions stands to offer a deeper sense of the impact of international law, which is so often experienced (or borne) far from the international courts, treaties, or governance bodies that establish the legal regime under examination. ' Studying the emotions that appear integral, epiphenomenal, aberrant, or even disruptive to the human practices that constitute international law can assist in developing a more critical understandings of them and, so too, the ways in which they work to support, or undermine, the principles, and norms of application they profess. ${ }^{10}$ As illustrated by Rebecca Sutton's work in this volume examining emotions in the context of international humanitarian law, the study of emotions can provide highly-detailed and layered portraits of legal practice. ${ }^{11}$ When studying how legal officials are applying law at the international or transnational level, or, conversely, how international law is implemented on the local level ${ }^{12}$, we might - for example - think it is important to know something about the impact of emotions on

9 See e.g. Pankaj Mishra, Age of Anger: A History of the Present, First American edition (New York: Farrar, Straus and Giroux, 2017); Sundhya Pahuja, Decolonising International Law: Development, Economic Growth and the Politics of Universality (Cambridge: Cambridge University Press, 2011), doi:10.1017/CBO9781139048200; José E. Alvarez, The Impact of International Organizations on International Law (Leiden ; Boston: Brill/Nijhoff, 2017).

10 Terry A. Maroney, "Law and Emotion: A Proposed Taxonomy of an Emerging Field.," Law and Human Behavior 30, no. 2 (2006): 119-42, doi:10.1007/s10979-006-9029-9.

${ }_{11}$ See e.g. Rebecca Sutton's chapter in this volume, "How the emotions and perceptual judgments of frontline actors shape the practice of International Humanitarian Law". ${ }_{12}$ See e.g. Megiddo, Tamar, "The Domestic Standing of International Law: A Non-State Account," Columbia Journal of Transnational Law 57 (2019): 494. 
perceptions and bias, ${ }^{13}$ the possibilities and politics of empathy, ${ }^{14}$ the disease of conceit, the effects of enmity, and anger on legal reasoning, ${ }^{15}$ and/or the consequences of apathy or emotional burn-out on law-making or adjudicatory efforts. ${ }^{16}$ In the field of international criminal law, for example, we might think it important to engage with work that queries oversimplified narratives linking trauma and truth-telling to emotional catharsis. ${ }^{17}$ The study of emotions broadens, even complicates, our understanding of legal actors, ${ }^{18}$ bringing to light fundamental questions from the role of emotions in legal reasoning, to the relationship between agents and structure, and right down into philosophical conceptions of the mind. Conceptualizations and explanations about practical activity, motivation, and intention all implicate emotion.

Scholars interested in the impact of an international or transnational legal regime (or in political change, historical contingency, and/or progress and decline narratives) might also wish to study emotions for their motivational aspects (Maria Pia Lara, for example, argues that aesthetic performances such as narratives and protests are more successful than reasoned dialogue in inspiring new and broader conceptions of social justice), ${ }^{19}$ for the ways in which they interact with our political attention, ${ }^{20}$ and the ways in which they can pull one's eye toward (or obscure altogether $^{21}$ the lived impacts of a legal regime. ${ }^{22}$ Some emotions

13 Susan A. Bandes, "Remorse and Criminal Justice," Emotion Review 8, no. 1 (January 2016): 14-19, doi:10.1177/1754073915601222.

14 See e.g. Lawrence Blum, “"Black Lives Matter': Moral Frames for Understanding the Police Killings of Black Males," in Virtue, Emotion and Imagination in Law and Legal Reasoning, ed. Amalia Amaya and Maksymilian Del Mar (Hart Publishing, 2020).

15 Terry Maroney, “Angry Judges,” Vanderbilt Law Review 65, no. 5 (2012): 1205-86.

16 See e.g. Stina Bergman Blix et al., "Introducing an Interdisciplinary Frontier to Judging, Emotion and Emotion Work," Oñati Socio-Legal Series 9, no. 5 (2019): 548-56.

17 See e.g. Sara Kendall and Sarah Nouwen, "Representational Practices at the International Criminal Court: The Gap Between Juridified and Abstract Victimhood", 76 Law and Contemporary Problems (2014), 235-262.

18 See e.g. Richard Ned Lebow, A Cultural Theory of International Relations (Cambridge, Cambridge University Press, 2009).

19 María Pía Lara, Moral Textures: Feminist Narratives in the Public Sphere (Berkeley, Calif.: University of California Press, 1998).

20 White, "On Emotions and the Politics of Attention in Judicial Reasoning."

21 See e.g. Andrea Bianchi and Anne Saab, "Fear and International Law-Making: An Exploratory Inquiry," Leiden Journal of International Law 32, no. 3 (September 2019): 351-65.

${ }_{22}$ We might here think of the international law projects that aim at generating data-based visualizations of human rights violations. See, e.g., the "Data Visualization for Human Rights Project" at the New York University School of Law Center for Human Rights and Global 
precipitate or compound an inability to pay quality attention to other persons, while other emotions play indispensable roles in fixing and holding attention on a subject. ${ }^{23}$ We might query whether there are emotions which spur on law-making processes at the international level (hope, rage, horror, oblivion)?

Theories of emotion also seem highly pertinent to biographical work in the field of international law where the aim is often to sketch something like a subjective portrait of a pivotal figure, revealing perhaps something new about the relationship between personality, historical context, action, intention and consequence. For such work, a theory of mind, ${ }^{24}$ and emotion is always at play, however buried, and it invariably includes ideas and claims about how conscious one might be of their own emotions, and/or those of others. ${ }^{25}$ The study of emotion seems similarly relevant for research efforts that examine the impact of certain immaterial forces such as the zeitgeist, or the mood of an age, or era (political crises for example often seem to suggest something of an emotional high-pitch, and/or an everything-is-illuminated visceral sense of certain stakes, which might be revealing, illusory, or entirely obscuring of other less visceral, or attention-grabbing, instances of structural political violence, environmental degradation, etc.).

Justice. Online at https://chrgj.org/focus-areas/data-visualization-for-human-rights/

${ }_{23}$ White, "On Emotions and the Politics of Attention in Judicial Reasoning."

24 See e.g. G. E. M. Anscombe, Intention, 2nd ed (Cambridge, Mass: Harvard University Press, 2000); David John Chalmers, The Conscious Mind: In Search of a Fundamental Theory, 1. issued as an Oxford University Press paperback, Philosophy of Mind Series (New York: Oxford Univ. Press, 1997).

${ }_{25}$ See e.g. Maria Aristodemou, Law and Psychoanalysis: Taking the Unconscious Seriously (Abingdon, Oxon; New York, NY: Routledge, 2014); Maria Aristodemou, "A Constant Craving for Fresh Brains and a Taste for Decaffeinated Neighbours," European Journal of International Law 25, no. 1 (February 1, 2014): 35-58, doi:10.1093/ejil/cht080; Alan W. Norrie, Law and the Beautiful Soul (London; Portland, Or. : Portland, Or: GlassHouse; Published in the United States by Cavendish Pub, 2005); Alan Norrie, "Animals Who Think and Love: Law, Identification and the Moral Psychology of Guilt," Criminal Law and Philosophy 13, no. 3 (September 2019): 515-44. See also, Robert Lowell, "Dolphin" "My eyes saw what my hand did" Selected Poems by Robert Lowell, published by Farrar, Straus \& Giroux, Inc. 1976, 1977. 


\section{Legal Reasoning/Legal Interpretation}

Research into the forms and practices of legal reasoning and interpretation are similarly enriched by the study of emotion. ${ }^{26}$ It is evident, for example, that legal texts sometimes involve emotion words ${ }^{27}$ (the search for remorse in sentencing ${ }^{28}$, the hate in hate $\operatorname{speech}^{29}$ ), or evaluative legal terms that have emotional resonances, such as equality, freedom, or dignity. ${ }^{30}$ We might ask how the hermeneutics of various international legal regimes differ, and how this relates to the roles that emotions play in the various practices of interpreting evaluative legal concepts?

Alternatively, one might also be interested in the emotional aspects of the materials that form part of the legal judgements, that are embedded within or invoked via the text of the judgement, i.e., the recitation of the facts, the woven-in metaphors, ${ }^{31}$ the use of past cases as analogies, the use of hypotheticals and exemplars, ${ }^{32}$ and the judgements overall style (or lack thereof) or prose. Or, one might wish to focus on the emotional aspects of the evidence or testimony that forms part of the legal record, and how these - perhaps even alongside the performances of the legal actors, ${ }^{33}$ or the aesthetics of the court room, impact legal reasoning. It seems an important question to determine how the law may or may not be able to bear (or even bear witness to) some of these emotional materials. ${ }^{34}$ One

\footnotetext{
26 See Amaya and Del Mar, Virtue, Emotion, and Imagination in Law and Legal Reasoning.

27 Maroney, "Law and Emotion."

28 Bandes, "Remorse and Criminal Justice."

29 See Jeremy Waldron, The Harm in Hate Speech, The Oliver Wendell Holmes Lectures, 2009

(Cambridge, Mass: Harvard University Press, 2012). See also, Saskatchewan (Human Rights

Commission) v. Whatcott, 2013 SCC 11, [2013] 1 S.C.R. 467.1

30 White, Emotions in Legal Reasoning. See, also, Tarunabh Khaitan, "Dignity as an Expressive Norm: Neither Vacuous Nor a Panacea," Oxford Journal of Legal Studies 32, no. 1 (March 1, 2012): 1-19.

31 See Maksymilian Del Mar, Artefacts of Legal Inquiry: The Value of Imagination in Adjudication (Oxford; New York: Hart, 2020).

32 See Maksymilian Del Mar, "Exemplarity and Narrativity in the Common Law Tradition," Law and Literature 25, no. 3 (November 2013): 390-427, doi:10.1525/lal.2013.25.3.390;

Maksymilian Del Mar and William Twining, Legal Fictions in Theory and Practice, (Cham: Springer International Publishing, 2015).

33 See e.g. Stina Bergman Blix and Åsa Wettergren, Professional Emotions in Court: A Sociological Perspective, 1 Edition (New York: Routledge, 2019).

34 Sara Kendall and Sarah Nouwen, "Representational Practices at the International Criminal
} 
significant site for exploration lies in the emotions of claimants reacting to what they see as the violence of state action and to what they or their lawyers might frame as a rights violation. Claimants may have such emotions as humiliation, ${ }^{35}$ rage, grief, indignation, and sorrow. The law has a language and a process. The emotions of claimants are mediated through laws of evidence and civil procedure. Legal processes take time. Lawyers work to reflect the humiliation, rage, grief, and sorrow of their clients by building a case that is recognizable by the court - a case that fits coherently into a line of precedent. This can be empowering. ${ }^{36}$ It can also be debilitating. It is critical to acknowledge the inexpressibility of some anguish and the inconsequence of legal remedy for some harms or wrongs ${ }^{37}$ It is also necessary to acknowledge the conservative nature of precedent, which tends to disregard those forms of harm, injury, social exclusion, or discrimination that appear to fall outside the recognized categories of legal rights violations.

\section{Foundations/Grounds}

A distinct set of reasons to study emotions in international law concerns the search for a common - or at least, solid - structure of human experience or human nature with which to establish a ground for critiquing existing political or legal arrangements. In the history of liberal political philosophy, emotions have long been a potential ground for constructing a theory of human nature which serves as a foundation for constructing arguments about legitimate political authority. We might think here of Hobbes building a political system out of a common fear of death, and a desire for commodious living. ${ }^{38}$ Or Hume who grounded ethical activity in the shared sentiment of beneficence, to argue (in

Court: The Gap between Juridified and Abstract Victimhood.(The Practices of the International Criminal Court)," Law and Contemporary Problems 76, no. 3-4 (2013): 235; Hannah Arendt, Eichmann in Jerusalem: A Report on the Banality of Evil, Penguin Classics (New York, N.Y: Penguin Books, 2006).

35 See Avishai Margalit, The Decent Society (Cambridge, Mass: Harvard University Press, 1996).

36 Patricia Williams, The Alchemy of Race and Rights (Boston: Harvard University Press, 1992).

37 I thank Megan Donaldson for raising this question. See e.g. Raimond Gaita, "On Dignity," in Philosophy, Ethics and a Common Humanity: Essays in Honour of Raimond Gaita, ed. Christopher Cordner (New York: Milton Park, Abingdon, Oxon: Routledge, 2017). 38 Thomas Hobbes and Crawford B. Macpherson, Leviathan, Repr, Penguin Classics (Harmondsworth: Penguin Books, 1988). 
something akin to an early critical genealogy) that justice was an artificial virtue that developed over time via the co-mingling of an ingrained sense of justice and a series of historically contingent community practices concerning property. ${ }^{39}$ Or we might think of Robin West writing in the 1989 Yale Journal of Law and Feminism that we should scrap much of everything to do with existing legal systems and begin again by constructing a feminist legal theory sourced directly from the emotions of love and rage. ${ }^{40}$

Normative arguments in legal and political thinking regularly smuggle into their premise's conceptions of human nature, and or human personality. ${ }^{41}$ Studying the assumptions at play about emotions in an argument about the authority of international law can further the critical work of unpacking its often-unspoken presumptions and premises. Human nature arguments can run in various directions claiming, for example, that certain political arrangements are necessary to enable or support human security, or human flourishing, to cure the hard-wired ills of human nature, or to prevent distortions in human personality (or, more subtlety, construct the possibilities for human personality). This is an old model of political argumentation that has seen explicit renewal in invocations of international human rights and human dignity. Probing the conception of emotion embedded within a theory about the political authority or legitimacy of governance activity beyond the state level can work to expose the broader working account of human nature (or other sorts of foundational claims about what human beings are like) that is often doing a lot of work in sustaining the overall argument. Set to light, such accounts can then be accepted, modified, or rejected at the level of detail or of form.

\footnotetext{
39 Hume, Warner, and Livingston, Political Writings.

40 Robin West, "Love, Rage and Legal Theory," Yale Journal of Law and Feminism 1, no. 1 (1989): 101-10.

${ }_{41}$ Christopher J. Berry, Human Nature, Issues in Political Theory (Atlantic Highlands, NJ: Humanities Press International, 1986).
} 


\section{The Politics of Sensibility}

A fourth script envisions the study of emotions in international law as a facet of an interest in sensibility, style ${ }^{42}$, aesthetics, or phenomenology, with proponents working through the ways in which emotions are shaped - or mutually constituted by political culture, by law, history and language, and/or deeper material realities/political economies. ${ }^{43}$ Work here might detail the emotional sensibility already demanded by the international laws that are in force in a particular place (even if that sensibility appears to be a cold, clinical one) by describing it, analyzing it, historicizing it, and/or by drawing attention to its material base. In the alternative, work in this area might focus on establishing (coaxing out, rediscovering, giving due regard etc. to that which has been politically marginalized) an alternative political sensibility, of solidarity for example, as a form of reaction or resistance. ${ }^{44}$ Here we might think of work unpacking the emotional architecture of a legal meeting, of jurisdictional overlap, ${ }^{45}$ or of a treaty. ${ }^{46}$ The study of emotion seems pertinent to those who are working to recover and call attention to those sensibilities towards international law or governance that have been long ignored or actively dismissed or dismantled. In this vein, we see powerful work emerging in the histories of international law and the field of international law and literature, ${ }^{47}$ which draws in work on the expressive or affective

42 As Randall Jarrell said of style, it "ought to make it easy for you to say all the you have to say, not, as most do, make it impossible for you to get free from one narrowed range of experience and expression." "The Humble Animal”, Jarrell, Poetry and the Age (London: Faber, 1996) at 158. See also, Gerry Simpson, The Sentimental Life of International Law: Literature, Language and Longing (Oxford: Oxford University Press, 2021).

43 See, e.g., Illan rua Wall, "The Ordinary Affects of Law," Law, Culture and the Humanities, November 16, 2019, 174387211988650, doi:10.1177/1743872119886509.

44 See e.g. John Borrows, Freedom and Indigenous Constitutionalism (Toronto; Buffalo; London: University of Toronto Press, 2016). Jessie Hohmann, ed., International Law's Objects, First Edition (Oxford, United Kingdom: Oxford University Press, 2018). Mishra, Age of Anger. Gerry

Simpson has been doing something like this in a piece called "gardening instead".

${ }_{45}$ See John Borrows, "Indian Agency: Forming First Nations Law in Canada," Political and Legal Anthropology Review 24, no. 2 (2001): 9-24, doi:10.1525/pol.2001.24.2.9.

${ }_{46}$ See e.g. Ruth Buchanan and Jeffery G Hewitt, "Treaty Canoe," in International Law's Objects, edited by Jessie Hohmanm and Daniel Joyce (Oxford University Press, 2018), 491-503, doi:10.1093/oso/9780198798200.003.0042.

${ }_{47}$ See e.g. the workshop series, "Literature and International Law: at the edge" convened by Joseph Slaughter (Columbia University), Vasuki Nesiah (New York University), Gerry Simpson (London School of Economics) and Christopher Gevers (University of KwaZulu-Natal).

Website: https://www.il-lit.org 
content $^{48}$ of international law. ${ }^{49}$ There are also emotion-rich histories of international law, ${ }^{50}$ and from a different angle much emerging work on the history of emotions, and the history of emotions in law, ${ }^{51}$ which aim to offer highly specific and detailed portraits of emotions in a snapshot of legal time. ${ }^{52}$ If emotions are well understood as bound up with ways of seeing, relating, being in the world, then perhaps work in the field of international law that probes broader historical-materialist planes might wish to think of the emotions that were made possible (or impossible) in various epochs, eras, or periods of time. ${ }^{53}$

48 See e.g. Mark A. Drumbl, "Memorializing Dissent: Justice Pal in Tokyo," AJIL Unbound 114 (2020): 111-16, doi:10.1017/aju.2020.26; Vidya Kumar, "Revolutionaries," in Concepts for International Law: Contributions to Disciplinary Thought, ed. Jean D'Aspremont and Sahib Singh (Cheltenham, UK: Edward Elgar Publishing, 2019); Joseph R. Slaughter, Human Rights, Inc. (Fordham University Press, 2007), doi:10.5422/fordham/9780823228171.001.0001.

49 See e.g. Kamari Maxine Clarke, Affective Justice: The International Criminal Court and the PanAfricanist Pushback (Durham: Duke University Press, 2019); Fleur Johns, The Non-Legal in International Law: Unruly Law (Cambridge: Cambridge University Press, 2012),

doi:10.1017/CBO9781139012959; Immi Tallgren and Thomas Skouteris, eds., The New Histories of International Criminal Law: Retrials, History and Theory of International Law (Oxford, United Kingdom: Oxford University Press, 2019); Gerry Simpson, "The Sentimental Life of International Law," London Review of International Law 3, no. 1 (March 1, 2015): 3-29, doi:10.1093/lril/lru013; Naz K. Modirzadeh, "Cut These Words: Passion and International Law of War Scholarship," Harvard International Law Journal 61, no. 1 (2020), doi:10.2139/ssrn.3485822; Wall, "The Ordinary Affects of Law."

50 As Nietzsche wrote in The Advantages and Disadvantages of History for Life, the living man uses history in three ways: for sources of grand companions and intensity; for finding loyalty, sentiment, belonging; and for collecting fire-fuel, bodies for bloodlettings (criticism).

51 See e.g. Kathryn Temple, Loving Justice: Legal Emotions in William Blackstone's England (New York: New York University Press, 2019).

52 See e.g. Sandra Schnädelbach, "The Voice Is the Message: Emotional Practices and Court Rhetoric in Early Twentieth Century Germany," Oñati Socio-Legal Series 9, no. 9(5) (December 1, 2019): 616-35, doi:10.35295/osls.iisl/0000-0000-0000-1030. Also, more generally, see the work at the Center for the History of Emotions at Max Planck Institute for Human Development (Berlin, Germany) and the Australian Research Council Centre of Excellence for the History of Emotions (The University of Western Australia).

${ }_{53}$ See e.g. Hila Keren's writing on neoliberal emotions in "Valuing Emotions" Wake Forest Law Review, Vol. 53, No. 5, 2018; Southwestern Law School Research Paper No. 2019/02. 


\section{Part II: Post-Script Questions - Conceptualizing Reach, Range and Recognition in the Study of Emotions}

... what scaffolded mind

Can rebuild experience

Philip Larkin, “A Stone Church Damaged

by a Bomb" 54

As the above section aims to show, there are several reasons why those studying international law might be interested in emotion. With respect to each of the above scripts, it will be important to consider how one is conceptualizing the reach, range, and recognition of emotions over time and place, including our ability to study emotions, our aptitude for recognizing our own emotions, and those of others, and any underlying assumptions about the relationship of emotions to knowledge claims. While some aspects of an emotion might appear to have universal features, ${ }^{55}$ a great deal often turns on the relation between a specific emotion and the context in which it is embedded. Emotions involve a physiological aspect (a pain or pleasure), and a judgment or evaluation of importance. ${ }^{56}$ Affectivity, understood as the experience of pain and pleasure, differentiates emotions from other modes of thought or experience. ${ }^{57}$ Some of the pains and pleasures relevant to emotions are of a particular sort: they are evaluative in the sense that they pick out and respond to features of the environment that the agent considers

54 Philip Larkin and Archie Burnett, The Complete Poems, 1. American paperback ed (New York: Farrar, Straus and Giroux, 2013).

55 .. Some psychologists have shown how anger flashes across faces in a similar manner in crosscultural studies, with a widening of the eyes and a tight-jawed bearing of the teeth. See e.g. Paul Ekman, Universals and Cultural Differences in Facial Expressions of Emotion (University of Nebraska Press Lincoln, 1971), Paul Ekman, 'Facial Expression and Emotion', American Psychologist, 48/4 (1993), 384, Paul Ekman, Darwin and Facial Expression: A Century of Research in Review (Malor Books, 2006). Charles Darwin, The Expression of Emotion in Man and Animals (Chicago: Chicago University Press, 1965). Antonio R. Damasio, Descartes' Error: Emotion, Reason, and the Human Brain (London: Penguin, 2005) xxiii, 312 p. Joseph E. Ledoux, The Emotional Brain: The Mysterious Underpinnings of Emotional Life (New York: Simon \& Schuster, 1996) $384 \mathrm{p}$.

56 John Gardner, "The Logic of Excuses and the Rationality of Emotions," Journal of Value Inquiry 43, 315-338 (2009); Solomon, The Passions.

57 Robinson, Deeper Than Reason: Emotion and Its Role in Literature, Music, and Art. 
important. ${ }^{58}$ As Michael Stocker writes, "there is far more to emotions than what is bodily...(and) this 'more' involves thoughts desires and values or evaluations." ${ }^{59}$ Where evaluative judgements are embedded within the structure of an emotion, we can expect it to be scripted, at least to an extent, by time and place (shaped by political and material realities, and prone to drawing on idiom, norms, caches of images, binaries, myths, etc. - and with all of this extending even to one's experience and description of the physiological aspects of emotions). ${ }^{60}$ This raises, in turn, questions of all sorts pertaining to the reach, range, and recognition of emotions between persons and groups, and these over space and time. ${ }^{61}$ This final section of the chapter poses two sets of questions raised by the literature on the philosophy of emotion to suggest that how one sets about to examine emotions in the territories of international law will largely depend on the answers to them that are either assumed or given.

\section{Questions of reach, questions of capture}

The first set of questions is already raised by the exercise of writing about emotions. What about emotions is it possible to capture through writing and study? What about emotions is it possible to capture in the study of law, or international law? There is a memorable scene in Mihail Sebastian's novel Two Thousand Years ${ }^{62}$ where the protagonist, a young scholar, passes a political march with his friend who is seized by the energy and expression of the crowd before seamlessly joining in. The protagonist also wishes to feel the hot, joyful solidarity of the gathering but finds himself invariably stuck outside the moment, watching himself as an external observer, analyzing the experience, feeling a heavy distance. ${ }^{63}$

\footnotetext{
58 White, Emotions in Legal Reasoning; Solomon, The Passions; Robinson, Deeper than Reason. 59 Michael Stocker and Elizabeth Hegeman, Valuing Emotions, Cambridge Studies in Philosophy (Cambridge [England]; New York: Cambridge University Press, 1996).

60 Solomon, Not Passion's Slave; Solomon, The Passions; Robinson, Deeper than Reason; Bernard Arthur Owen Williams, Shame and Necessity, New ed, Sather Classical Lectures 57 (Berkeley, Calif.: University of California Press, 2008).

${ }_{61}$ See e.g. Williams, Shame and Necessity.

${ }^{62}$ Mihail Sebastian and Seán Ó Ceallaigh, For Two Thousand Years, Penguin Modern Classics (UK: Penguin Books, 2016).

63 Nietzsche writing about the Ancient Greeks famously mourns the impossibility of absorption, which is something akin to a full-blooded, un-self-conscious, unironic engagement, in modern thinking in Friedrich Wilhelm Nietzsche, On the Advantage and Disadvantage of History for Life (Indianapolis: Hackett Pub. Co, 1980).
} 
The scene raises the question as to whether an emotional state might be capturable or cognizable from an outside perspective? ${ }^{64}$ How might the answer to this question change were we to understand emotions to reflect a politics, ${ }^{65}$ a political time, ${ }^{66}$ an ethic ${ }^{67}$ and/or a way of seeing? ${ }^{68}$ All of these questions engage deep epistemological questions about the relationship between emotions and understanding. Bernard Williams notably raised similar questions in his book, Shame and Necessity, ${ }^{69}$ which considers whether and how the "modern" western reader might grasp ancient Greek tragedies and understand their daemonic worldview conceptions of necessity and shame vis-à-vis post-Kantian and Christian conceptions of autonomy and guilt, imbued as they are with disparate social and moral landscapes and metaphysical assumptions.

A related background question concerns whether the research and study of emotions alters them? Can research methods grasp their subject, "pinned and wriggling on the wall"? ${ }^{70}$ One criticism of the law and emotions field is the tendency to offer overly rationalized descriptions of emotions (often casting emotions just like other forms of reasons for action) in order to render them more recognizable to the subject of law, and/or legal reasoning. ${ }^{71}$ Questions remain, however, as to whether emotions have something like an elusive quality, and whether they are

${ }^{64}$ We might think here of how calls for solidarity in social movements can sometimes leave academics feeling impotent, removed, wrong-tooled or heavy-footed. Or of Philip Larkin writing about the end of love: "Standing on love's further shore" as Larkin coolly put it in his poem, "Prologue". Or see Sigrid Nunez in the New York Review of Books for a discussion on Garth Greenwell's novels and the trickiness of writing about sex in fiction boiling down to the fact that absent a state of arousal much of the language to describe sexual activity appears staid, hackneyed, and ridiculous. Sigrid Nunez, "Sex and Sincerity," The New York Review of Books, June 11, 2020.

${ }_{65}$ Amia Srinivasan, "The Aptness of Anger," Journal of Political Philosophy 26, no. 2 (June 2018): 123-44; Audre Lorde, Sister Outsider: Essays and Speeches (Berkeley, Calif: Crossing Press, c2007, n.d.).

${ }_{60}$ See Mishra, Age of Anger.

67 On emotions as the foundation of ethics, see Hume, Warner, and Livingston, Political Writings; Charles Leslie Stevenson, "The Emotive Meaning of Ethical Term," Mind XLVI, no. 181 (1937): 14-31, doi:10.1093/mind/XLVI.181.14; Solomon, The Passions; Jesse Prinz, "The

Emotional Basis of Moral Judgments," Philosophical Explorations 9, no. 1 (March 2006): 29-43; Jesse Prinz, The Emotional Construction of Morals (Oxford University Press, 2009).

68 Jean-Paul Sartre, Sketch for a Theory of the Emotions, Reprint, Routledge Classics (London: Routledge, 2006); Solomon, The Passions.

69 Williams, Shame and Necessity.

70 "The Love Song of J. Alfred Prufrock" in Thomas Stearns Eliot, Collected Poems, 1909-1962, Centenary ed. (New York: Harcourt Brace Jovanovich, 1991).

71 White, Emotions in Legal Reasoning. 
well understood by the self? ${ }^{72}$ We might ask in what ways are emotions private $?^{73}$ Stephen Leighton holds the view that the feeling aspects of emotions are private, writing that:

(s)erious discussion of feelings is made difficult because feelings, whatever their precise nature and role, occupy a particularly private part of our psychic life...(s)ince these difficulties are inherent in the subject matter, we can never enjoy the sort of sophistication in discrimination or comparison concerning feelings which we enjoy with, say, the cognitive components of emotion. ${ }^{74}$

Further on the subject of capture, we might ask whether we can study the emotions of legal actors by reference to legal documents, evidentiary records, legislative speeches ${ }^{75}$ judgements ${ }^{76}$ If so, are we studying the emotions of these legal actors, or the expression (even performance) of their emotions, the quality of their speech, writing, prose, or something else? ${ }^{77}$ What of documents written in concert? Or of legal judgements aiming to capture the ear of the public, or to escape the eye of an appellate court? How and when does legal language reveal emotion? ${ }^{78}$ Whose emotions? Philosophers of emotion have long puzzled through questions about emotions and time (often assumptions about the expected duration of an emotion, for good or ill, serve as stamps of authentication, i.e., is it grief without the long drift, anger without flint, love if it retreats in the cold morning light?)..$^{79}$ And so too, how emotions change when we fold experiences, including emotional experiences into narratives - drawing in patterns, and political histories (for example, an incident which frightened us, might upon reflection raise laughter, indignation, or

72 See e.g. Aristodemou, Law and Psychoanalysis; Aristodemou, "A Constant Craving for Fresh Brains and a Taste for Decaffeinated Neighbours"; Norrie, "Animals Who Think and Love."

73 See e.g. Stephen R. Leighton, "A New View of Emotion," American Philosophical Quarterly 22, no. 2 (1985): 133-41.

74 Leighton, Philosophy and the Emotions: A Reader at 276.

75 Carol Sanger, "Legislating with Affect: Emotion and Legislative Law Making," Nomos 53 (2013): 38-76.

76 See White, Emotions in Legal Reasoning. Maroney, "Law and Emotion."

77 On the performance of emotion in the courtroom, see Blix and Wettergren, Professional Emotions in Court; Stina Bergman Blix and Åsa Wettergren, "A Sociological Perspective on Emotions in the Judiciary," Emotion Review 8, no. 1 (January 2016): 32-37.

78 See Maroney, "Law and Emotion."

79 Goldie, "Narrative Thinking, Emotion, and Planning"; Leighton, Stephen R., "A New View of Emotion," American Philosophical Quarterly 22 (1985); White, "On Emotions and the Politics of Attention in Judicial Reasoning." 
rage). ${ }^{80}$ On the subject of time, law and emotion, Susan Bandes has written of how the emotion of remorse implicates something of a future gaze, and a promise of better behaviour, finding, devastatingly, that judges are often less apt at reading a concrete future (full of family, success, education, etc.) for poor and/or racialized defendants, and hence are less likely to attribute to them the emotion of remorse, a factor which has concrete consequences in terms of sentencing. ${ }^{81}$

There are also questions concerning the formality, and highly structured nature of legal writing and reasoning. ${ }^{82}$ What is the assumed relationship between sincerity and form? ${ }^{83}$ There is a difference between chronicling emotions and experiencing emotions. ${ }^{84}$ There is a difference between using emotion words, like guilt and love, and experiencing either of these things. ${ }^{85}$ How wide's the chasm? These questions are relevant when we think of studying the emotions that get translated (or transmuted) through the rules of evidence, and testimony, the norms of judgement writing, and through legal language, and legal concepts of law, which themselves often contain emotional and expressive content. ${ }^{86}$

Some philosophers of emotion have attempted to make sense of these distinctions by insisting that emotions have physiological components. ${ }^{87}$ One might, for example, hold the particular set of evaluative judgments that are characteristic of an emotion but might not be considered to be experiencing that emotion where they lack its characteristic feeling or

${ }^{80}$ White, "On Emotions and the Politics of Attention in Judicial Reasoning"; Goldie,

"Narrative Thinking, Emotion, and Planning."

81 Susan A. Bandes, "Remorse and Demeanor in the Courtroom: Cognitive Science and the Evaluation of Contrition," in About the Integrity of Criminal Process: From Theory into Practice, 1st ed. (Hart Publishing, 2016).

${ }_{82}$ See Amaya and Del Mar, Virtue, Emotion, and Imagination in Law and Legal Reasoning; Del Mar, "Exemplarity and Narrativity in the Common Law Tradition."

83 Goldie, "Narrative Thinking, Emotion, and Planning." Also, W.H. Auden on form, paraphrasing Paul Valéry: "a person is a poet if his imagination is stimulated by the difficulties inherent in his art and not if his imagination is dulled by them." "W. H. Auden, The Art of Poetry No. 17," The Paris Review, Spring 1974,

https://www.theparisreview.org/interviews/3970/the-art-of-poetry-no-17-w-h-auden.

${ }_{84}$ White, "On Emotions and the Politics of Attention in Judicial Reasoning."

85 White, Emotions in Legal Reasoning.

86 See Khaitan, "Dignity as an Expressive Norm”; White, Emotions in Legal Reasoning; Nussbaum, Hiding from Humanity.

87 Robinson, Deeper than Reason; De Sousa, The Rationality of Emotion; Solomon, The Passions. 
physiological aspect. ${ }^{88}$ Aristotle argued that the emotion of anger followed from the recognition that a slight towards oneself or one's friends had occurred. One might, however, understand perfectly well that they've been slighted and yet feel nothing. Should they be described as angry? What if they use the judgment as a reason for action, or play up the role? What if the physiological aspects of the emotion lag, or are repressed, or projected? A common error is to assume that emotions or emotional reactions occur only in extreme states or are detectable only in overwrought descriptions. ${ }^{89}$ Combatting the idea that emotional reactions were always over-reactions, and/or the source of undisciplined, specious reasoning, there's John Gardner's memorable lines:

there is no general or default answer to the question of whether a sober appreciation of reasons for action is more reasonable than an emotionallycharged appreciation of those same reasons for action. Being cool, calm, and collected is just another place on the emotional map, with no special claim to rational efficiency. ${ }^{90}$

\section{Questions of recognition and range}

The above set of questions concerned what might be possible to capture and study about emotions in the theory and practice of international law. This second series of questions concerns the recognition of others, including the emotions of others, through emotions themselves. Which emotions, for example, facilitate recognition, respect, justice, dignity, solidarity? Under which circumstances? How might we conceptualize or examine one's range of emotional concern? Or the politics and quality of that emotional concern? Or the barriers to emotional concern? ${ }^{91}$

${ }^{88}$ Leighton, Stephen R., "A New View of Emotion.”

89 Israel Scheffler makes a similar argument in a short essay entitled "Ten Myths about Metaphor," in Israel Scheffler, In Praise of the Cognitive Emotions (London: Routledge, 1991). See, e.g. how the controlled prose of modern poetry can strike as utterly devastating, as in "One Art" in Elizabeth Bishop, The Complete Poems 1926-1979 (New York: Farrar, Straus and Giroux, 1983). See also Randall Jarrell, Poetry and the Age (London: Faber, 1955) 240.

90 Gardner, 'The Logic of Excuses and the Rationality of Emotions', at 349.

91 See e.g. Lawrence Blum, “Black Lives Matter': Moral Frames for Understanding the Police Killings of Black Males," in Virtue, Emotion and Imagination in Law and Legal Reasoning, ed. Amalia Amaya and Maksymilian Del Mar (Hart Publishing, 2020), 121-38. 
Ilya Kaminsky's Deaf Republic ${ }^{92}$ is an epic series of poems about a fictionalized town under occupation whose people take up deafness (conceptualized as a meaning-rich, power-filled refusal of sound, not a lack) as a political mode of resistance. In an early poem, entitled, "Deafness, an insurgency begins", a member of an occupying force barks orders at a citizen, who raises her finger to point at her ear, signalling a message not received, a refusal. The image is of incommensurability as resistance, a communication blockade. In a later poem this stance comes to feel like a 'natural' or spontaneous response to many of the townspeople living under the occupation. This book of poems, amongst other things, raises questions about the role emotions play in the political recognition of others as equals.

Robert Solomon describes some emotions as having an intersubjective focus, meaning that they aim at an understanding that sits, in a sense, somewhere between the person experiencing the emotion and its subject. ${ }^{33}$ Solomon offers pity as an example of such an emotion, and uses this criterion of intersubjectivity to illustrate how ill-versions of the emotion might arise. If the focus of pity, for example, moves too close to the self and away from its subject, it risks becoming narcissistic and/or self-indulgent. If it moves too far away from the self, the suffering of another might fail to register as it should or might have, causing one, at times, to be obtuse, heedless, hard-hearted, or cruel. ${ }^{94}$ This view echoes in John Berger's 'Photographs of Agony', though it is cast there in explicitly political terms. ${ }^{95}$ Berger writes how the mind can move inwards to wrestle with questions of moral inadequacy after witnessing a photograph depicting anguish or horror, in a process that effectively transmutes the reality of the other into a private, general and abstract, existential question that remains far removed from the concrete political realities that precipitated the war, the attack, the mass drowning, the famine, etc. Where, for Berger, the angst felt by the witness does result in action, it is

\footnotetext{
92 Ilya Kaminsky, Deaf Republic: Poems (Minneapolis, Minnesota: Graywolf Press, 2019).

93 Solomon, Not Passion's Slave.

94 Where the affective component of pain and concern is traded for pleasure, the suffering of others could result in gawking or titillation. See White, Emotions in Legal Reasoning.

95 John Berger et al., Ways of Seeing (London: Penguin Books, 2008).
} 
invariably token if it is aimed at relieving their internal discomfort as opposed to a move towards political recognition, or an act of confrontation or resistance.

Sociologists of punishment have long written about witnessing pain without experiencing pain. ${ }^{96}$ Must, for example, a recognition of kinship or equality always precede the "sharing of another's pain," or might the witnessing of another's pain instigate and/or facilitate this recognition of kinship or equality. This is a critical sequencing question. Lynn Hunt has argued the latter position, suggesting that, over time, literary depictions of pain and suffering have worked to generate more inclusive conceptions of justice through empathy. ${ }^{97}$ Hans Joas resists this view by using historical examples to illustrate how the pain of "the other" remained unseen and un-affecting prior to the recognition that they were sacred or equal. ${ }^{98}$ While these views needn't be mutually exclusive, the productive potential of emotions like empathy in the law rests on the sequencing of pain and recognition that the emotion is presumed to entail. ${ }^{99}$

At times, painful emotions serve epistemic functions, aiding our understanding of the situation we are confronting. ${ }^{100}$ Pain, up to a point, can facilitate focus and attention. In this way, it has the potential to be clarifying, just as anger can be a form of right-seeing. ${ }^{101}$ All emotions have a built-in desire, and painful emotions have a built-in desire to locate the source of the pain. ${ }^{102}$ Emotional reactions, such as horror, indignation, or political anger, ${ }^{103}$ can also serve to highlight the hypocritical nature of a

96 David Garland, Punishment and Modern Society: A Study in Social Theory, Studies in Crime and Justice (Chicago: University of Chicago Press, 1990); Michel Foucault, Discipline and Punish: The Birth of the Prison, 2nd Vintage Books ed (New York: Vintage Books, 1995).

97 Lynn Hunt, Inventing Human Rights: A History (New York: W.W. Norton \& Co, 2007).

98 Hans Joas, The Sacredness of the Person: A New Genealogy of Human Rights (Washington, D.C: Georgetown University Press, 2013).

99 White, Emotions in Legal Reasoning; Emily Kidd White, "Till Human Voices Wake Us," Journal of Law, Religion and State 3 (2014): 201.

100 Michael S. Brady, Emotional Insight: The Epistemic Role of Emotional Experience (Oxford University Press, 2013).

101 Srinivasan, “The Aptness of Anger." See also, Catherine Z Elgin, "Impartiality and Legal Reasoning," in Virtue, Emotion and Imagination in Law and Legal Reasoning, ed. Amalia Amaya and Maksymilian Del Mar (Hart Publishing, 2020), doi:10.5040/9781509925162.

102 Solomon, Not Passion's Slave. Gardner, "The Logic of Excuses and the Rationality of Emotions."

103 Srinivasan, "The Aptness of Anger." 
legal order by juxtaposing the impact of a law's publicly stated purpose, against its impact. ${ }^{104}$ The attention-directing features of emotions are far from apolitical, and raise a series of questions about whose emotions are legible to those in power, and whose emotions are perceived to be legitimate, compound, deeply-felt, or authentic. ${ }^{105}$

In a different but related vein we might worry about the arrogance (one that seems easily compounded by racist, classist, or gendered stereotypes) in assuming the legibility of the emotions of others over time and place. Iris Murdoch has written powerfully on the need to generate new ethical concepts that respect the gravity and complexity of the other. ${ }^{106}$ Murdoch writes:

we derive from Kant, and also Hobbes and Bentham through John Smart Mill, a picture of the individual as a free rational will. With the removal of Kant's metaphysical background this individual is seen as alone. (He is in a certain sense alone on Kant's view also, that is: not confronted with real dissimilar others.) 107

Elsewhere I have written about the error of empathy that occurs where legal actors, operating under the assumption that there are no deep or difficult to access differences between persons and how they experience the law, imagine themselves into the legal and/or social position of the claimant in a manner which serves to co-opt their stories and experiences into a pre-existing narrative. ${ }^{108}$ In earlier writings, I've drawn on the work of Simone Weil to illustrate how pain experienced by others might be erased, or found to be titillating. Others have detailed how empathy is often highly selective, frequently moralized, and dependent upon (often highly problematic) notions of desert and agency, and much has been written on the ways in which racist, classist, and gendered prejudices and stereotypes can foreclose the possibility of empathy. ${ }^{109}$

104 See e.g. Patricia J. Williams, "The Raw and the Half-Cooked," in The Humanities and Public Life, ed. Peter Brooks and Hilary Jewett, First edition (New York: Fordham University Press, 2014).

105 Bandes, "Remorse and Criminal Justice."

106 Iris. Murdoch, "Against Dryness: A Polemical Sketch," Encounter, 1961; Iris. Murdoch, Metaphysics as a Guide to Morals, 1st American ed. (New York: The Penguin Press, 1993).

107 Murdoch, "Against Dryness: A Polemical Sketch."

108 White, "On Emotions and the Politics of Attention in Judicial Reasoning."

109 Amy Coplan and Peter Goldie, eds., Empathy: Philosophical and Psychological Perspectives 
The unforgettable lyrical prelude to Kaminsky's book of poems is entitled, We Lived Happily During the War ("And when they bombed other people's houses, we/protested/ but not enough, we opposed them but not enough... in the street of money in the city of money in the country of money/our great country of money, we (forgive us)/lived happily during the war.") ${ }^{110}$ The poem points to the wrongness and/or betrayal of living happily amidst great suffering (perhaps even at the expense of another's suffering). It concerns the failure to respond emotionally where one has political, or moral reasons to do so. This raises an additional series of questions concerning how one's range of emotional concern might be extended, and the ways in which they might be extended in line with one's political, ethical or justice-based commitments? How utilitarian might this calculation be? Thinking about the role emotions might play in the service of justice raises a series of subtle questions about emotions and truth or knowledge claims, and about the rationality of emotions themselves.

Within the field of the philosophy of emotion, it is a long-abandoned view that emotions are beyond judgement, or political evaluation, though this is often the stated rationale for the call to disentangle legal reasoning from emotion. Emotions are, however, evaluative in at least two senses. Emotions are object-directed, which means that facts or new information about an object can work to revise an emotional state. ${ }^{111}$ Emotions are also comprised of cognitive judgements reflecting in some sense what the person experiencing the emotion considers important, which opens them up to probing questions about the status of the values underlying those emotional concerns. It is with respect to the former that perspectival understandings of law can work to illustrate how certain histories, experiences, and proximity to the impact of a legal regime serve to lend a credibility, weight, or rationality to certain emotional expressions over

(Oxford; New York: Oxford University Press, 2011); White, "On Emotions and the Politics of Attention in Judicial Reasoning”; Paul Bloom, Against Empathy: The Case for Rational Compassion (New York: Ecco, 2018); Sally Anne Haslanger, Resisting Reality: Social Construction and Social Critique (New York: Oxford University Press, 2012); Miranda Fricker, Epistemic Injustice: Power and the Ethics of Knowing (Oxford; New York: Oxford University Press, 2007).

${ }_{110}$ "We Lived Happily During the War" in Kaminsky, Deaf Republic.

111 Nussbaum, Upheavals of Thought; Solomon, The Passions. 
others. ${ }^{112}$ In a powerful debate over the political virtue of anger, Amia Srinivasan responds to Martha Nussbaum's argument that anger is politically unproductive and morally damaging by raising the history of black feminists who have long defended the rationality, and psychic significance of anger, as a powerful means of acknowledging political injustice. ${ }^{113}$ While truth and/or rationality claims about emotions can play foundational roles in political and justice-based arguments, it is also worthwhile to explore the ways in which emotions can contribute to political projects (perhaps via literature, aesthetics, communal movements, radically imagined futures etc.) without necessarily drawing on the language of truth, rationality, or reason. ${ }^{114}$

We might also like to puzzle through standing assumptions about emotions and their relationship to knowledge and bodies. While the cognitive view of emotions tends to be preeminent (for the time being) in the field of the philosophy of emotion, other philosophical conceptions of emotion foreground their affective and bodily aspects. William James famously wrote of how emotions were felt first in the body - with old evolutionary structures of the brain trained to spur reactions like flight. These experiences (the widened pupil, the quickened heartbeat) are later processed into emotion words and experiences, such as fear, or shame. Jenefer Robinson's account of emotions - of "emotions-as-process" similarly foregrounds the affective or physiological aspect of emotions. She writes that emotions consist of an initial affective appraisal of something that the agent considers important, and at this stage, "our emotional pathways are fast and 'dirty', emphasizing the situation as perceived in terms of one's interests and desires." ${ }^{115}$ Robinson suggests that is useful to think of affective appraisals "as a kind of 'meta-response', evaluating in a rough and ready way" something in the internal or

\footnotetext{
112 See e.g. Williams, "The Raw and the Half-Cooked"; Peggy Cooper Davis, "Responsive Constitutionalism and the Idea of Dignity," University of Pennsylvania Journal of Constitutional Law 11, no. 5 (2009): 1373; Jedediah Purdy, "Laundered Violence: Law and Protest in Durham," N+1, August 23, 2017, https://nplusonemag.com/online-only/online-only/laundered-violence/.

113 See Srinivasan, "On the Aptness of Anger".

114 See e.g. Gabrielle Bellot, "Gabrielle Bellot on the Dreamy, Queer Beauty of On a Sunbeam," Literary Hub, May 28, 2019, https://ithub.com/gabrielle-bellot-on-the-dreamy-queer-beautyof-on-a-sunbeam/.

115 Robinson, Deeper than Reason.
} 
external environment that matters to the individual in question, which then precipitates a physiological response (slowed breathing, a shiver down the spine). The process ends with cognitive reflection, which layers on social meaning. We are thinking creatures, and we think through (justify, correct, temper) our responses. ${ }^{116}$

A final distinct but related question concerns the political value of what is captured by and through emotions? What are the affective aspects of solidarity? What is the difference between an emotion-soaked witness, and voyeurism? Are there material, political, legal, constitutional prerequisites for feelings associated with solidarity, equality, or dignity? ${ }^{117}$ What is the relationship between imagination and emotion? ${ }^{118}$ How might one study emotions in international law without falling into a sort of scholarly preciousness or dilettantism - grave errors each given the long-running structural, colonial, material violence associated with the history of the field. ${ }^{119}$ How to guard against the wrong or betrayal of drawing on the materials of international law to showcase one's own fineness of sensibility for reading or writing about the subject? How might we cut at the distinction between sentiment and sentimentality? ${ }^{120}$ How might associations between emotions and virtue (or fineness/sensibility/sensitivity) resist elitism, and contend with rule of law concerns? ${ }^{121}$

116 See e.g. Thomas Nagel, Concealment and Exposure: And Other Essays (Oxford; New York: Oxford University Press, 2002).

117 Rocio Lorca, "Punishing the Poor and the Limits of Legality," Law, Culture and the Humanities, July 23, 2018, 174387211878998, doi:10.1177/1743872118789985.

118 See e.g. Amaya and Del Mar, Virtue, Emotion, and Imagination in Law and Legal Reasoning.

119 This cutting criticism was raised in Christine Schwöbel-Patel's lecture entitled,

"Occupying' Global Justice: Towards a Counter-Aesthetics of Marketised Global Justice” at Osgoode Hall Law School on February 27, 2019. See also the forthcoming book, Christine Schwöbel-Patel, Marketing Global Justice: The Political Economy of International Criminal Law, Cambridge Studies in International and Comparative Law 152 (Cambridge: Cambridge University Press, 2021).

120 .. See Catherine Z Elgin, "Impartiality and Legal Reasoning," in Virtue, Emotion and Imagination in Law and Legal Reasoning, ed. Amalia Amaya and Maksymilian Del Mar (Hart Publishing, 2020), doi:10.5040/9781509925162. Gerry Simpson locates this tension in the practice of international law in "The Sentimental Life of International Law," London Review of International Law 3, no. 1 (March 1, 2015): 3-29.

121 Elgin, "Impartiality and Legal Reasoning." 


\section{Conclusion}

The final poem in Kaminsky's book sees the fictionalized occupied town left by the narrator for present day America. The poem is entitled, "In a Time of Peace" 122 , a section of which reads, "Ours is a country in which a boy shot by police lies on the pavement/for hours./ We see in his open mouth/ the nakedness/ of the whole nation./ We watch. Watch/ others watch. / The body of a boy lies on the pavement exactly like the body of a boy." The poem, as I understand it, is referring to the police shooting of an unarmed black teenager Michael Brown, and the grave dishonour, and disregard, shown from the act of letting his lifeless body lie on the pavement for hours, as the surrounding community gathered to give witness. Brown is not mentioned by name in the poem, nor his town of Ferguson, Missouri. As one reads the poem, the reference is known, or not known, and one final question for this chapter is what turns on this? It raises a question, long grappled with in the study of the history of political thought (and so too with respect to the history of the philosophy of mind and knowledge), which is, how much context and detail is required for understanding? We might ask here after the role of detail in constructing affect. What is it necessary to know to share in the rage and mourning called for by allusion to the killing in the poem? What details impact the shape of this rage and this mourning? Or the duration of this rage and this mourning? What is lost in broad comparative work? What is gained?

This chapter represents only a first effort at generating a series of questions that seem invariably raised by any study of emotions in the territories of international law. Many of these are overwhelmingly large, implicating whole systems of knowledge, philosophies of action, theories of history, theories of human nature, and so on. Nevertheless, we must ask them as our answers to these questions, however buried or explicit, set our terms, and frames, and associations for the research that follows.

Kaminsky, Deaf Republic. 


\section{Bibliography}

Alvarez, José E. The Impact of International Organizations on International Law. Leiden; Boston: Brill/Nijhoff, 2017.

Amaya, Amalia, and Maksymilian Del Mar, eds. Virtue, Emotion, and Imagination in Law and Legal Reasoning. Chicago: Hart Publishing, an imprint of Bloomsbury Publishing, 2020.

Anscombe, G. E. M. Intention. 2nd ed. Cambridge, Mass: Harvard University Press, 2000.

Arendt, Hannah. Eichmann in Jerusalem: A Report on the Banality of Evil. Penguin Classics. New York, N.Y: Penguin Books, 2006.

Aristodemou, Maria. "A Constant Craving for Fresh Brains and a Taste for Decaffeinated Neighbours." European Journal of International Law 25, no. 1 (February 1, 2014): 35-58. doi:10.1093/ejil/cht080.

- - Law and Psychoanalysis: Taking the Unconscious Seriously. Abingdon, Oxon; New York, NY: Routledge, 2014.

Bandes, Susan A. "Remorse and Criminal Justice." Emotion Review 8, no. 1 (January 2016): 14-19. doi:10.1177/1754073915601222.

- - . "Remorse and Demeanor in the Courtroom: Cognitive Science and the Evaluation of Contrition." In About the Integrity of Criminal Process: From Theory into Practice, 1st ed. Hart Publishing, 2016.

—__, ed. The Passions of Law. Critical America. New York: New York University Press, 1999.

Bellot, Gabrielle. "Gabrielle Bellot on the Dreamy, Queer Beauty of On a Sunbeam.” Literary Hub, May 28, 2019. https://lithub.com/gabriellebellot-on-the-dreamy-queer-beauty-of-on-a-sunbeam/.

Berger, John. Ways of Seeing. London: Penguin Books, 2008. 
Bergman Blix, Stina, and Åsa Wettergren. "A Sociological Perspective on Emotions in the Judiciary.” Emotion Review 8, no. 1 (January 2016): 32-37. doi:10.1177/1754073915601226.

Berry, Christopher J. Human Nature. Issues in Political Theory. Atlantic Highlands, NJ: Humanities Press International, 1986.

Bianchi, Andrea, and Anne Saab. "Fear and International Law-Making: An Exploratory Inquiry.” Leiden Journal of International Law 32, no. 3 (September 2019): 351-65. doi:10.1017/S0922156519000177.

Blix, Stina Bergman, and Åsa Wettergren. Professional Emotions in Court: A Sociological Perspective. 1 Edition. New York: Routledge, 2019.

Bloom, Paul. Against Empathy: The Case for Rational Compassion. New York: Ecco, 2018.

Blum, Lawrence. "“Black Lives Matter': Moral Frames for Understanding the Police Killings of Black Males." In Virtue, Emotion and Imagination in Law and Legal Reasoning, edited by Amalia Amaya and Maksymilian Del Mar, 121-38. Hart Publishing, 2020. doi:10.5040/9781509925162.

Borrows, John. Freedom and Indigenous Constitutionalism. Toronto; Buffalo; London: University of Toronto Press, 2016.

-_- "Indian Agency: Forming First Nations Law in Canada." Political and Legal Anthropology Review 24, no. 2 (2001): 9-24. doi:10.1525/pol.2001.24.2.9.

Brady, Michael S. Emotional Insight: The Epistemic Role of Emotional Experience. Oxford University Press, 2013.

Buchanan, Ruth, and Jeffery G Hewitt. "Treaty Canoe." In International Law's Objects, edited by Jessie Hohmann and Daniel Joyce, 491-503. Oxford University Press, 2018.

Chalmers, David John. The Conscious Mind: In Search of a Fundamental Theory. 1. issued as an Oxford University Press paperback. Philosophy of Mind Series. New York: Oxford Univ. Press, 1997. 
Clarke, Kamari Maxine. Affective Justice: The International Criminal Court and the Pan-Africanist Pushback. Durham: Duke University Press, 2019.

Coplan, Amy, and Peter Goldie, eds. Empathy: Philosophical and Psychological Perspectives. Oxford; New York: Oxford University Press, 2011.

Crawford, James. Brownlie's Principles of Public International Law. New York, NY: Oxford University Press, 2019.

Crawford, James, Martti Koskenniemi, and Surabi Ranganathan. The Cambridge Companion to International Law. Cambridge: Cambridge University Press, 2015.

Darwin, Charles, and Paul Ekman. The Expression of the Emotions in Man and Animals. 3rd ed. London: HarperCollins, 1998.

Davis, Peggy Cooper. "Responsive Constitutionalism and the Idea of Dignity." University of Pennsylvania Journal of Constitutional Law 11, no. 5 (2009): 1373.

De Sousa, Ronald. The Rationality of Emotion. 1. paperback ed., 5. print. Bradford Books. Cambridge, Mass.: MIT Press, 1997.

Deigh, John. Emotions, Values, and the Law. Oxford; New York: Oxford University Press, 2008.

Del Mar, Maksymilian. Artefacts of Legal Inquiry: The Value of Imagination in Adjudication. Oxford; New York: Hart, 2020.

-_- "Exemplarity and Narrativity in the Common Law Tradition." Law and Literature 25, no. 3 (November 2013): 390-427. doi:10.1525/lal.2013.25.3.390.

Del Mar, Maksymilian, and William Twining. Legal Fictions in Theory and Practice, 2015.

Dorsett, Shaunnagh, and Shaun McVeigh. Jurisdiction. Milton Park, Abingdon, Oxon; New York, NY: Routledge, 2012. 
Drumbl, Mark A. "Memorializing Dissent: Justice Pal in Tokyo." AJIL Unbound 114 (2020): 111-16. doi:10.1017/aju.2020.26.

Ekman, Paul, and Richard J. Davidson, eds. The Nature of Emotion: Fundamental Questions. Series in Affective Science. New York: Oxford University Press, 1994.

Elgin, Catherine Z. "Impartiality and Legal Reasoning." In Virtue, Emotion and Imagination in Law and Legal Reasoning, edited by Amalia Amaya and Maksymilian Del Mar. Hart Publishing, 2020. doi:10.5040/9781509925162.

Eliot, Thomas Stearns. Collected Poems, 1909-1962. Centenary ed. New York: Harcourt Brace Jovanovich, 1991.

Foucault, Michel. Discipline and Punish: The Birth of the Prison. 2nd Vintage Books ed. New York: Vintage Books, 1995.

Fricker, Miranda. Epistemic Injustice: Power and the Ethics of Knowing. Oxford; New York: Oxford University Press, 2007.

Gaita, Raimond. "On Dignity." In Philosophy, Ethics and a Common Humanity: Essays in Honour of Raimond Gaita, edited by Christopher Cordner. New York: Milton Park, Abingdon, Oxon: Routledge, 2017.

Gardner, John. "The Logic of Excuses and the Rationality of Emotions," Journal of Value Inquiry 43, 315-338 (2009).

Garland, David. Punishment and Modern Society: A Study in Social Theory. Studies in Crime and Justice. Chicago: University of Chicago Press, 1990.

Goldie, Peter. "Narrative Thinking, Emotion, and Planning." The Journal of Aesthetics and Art Criticism 67, no. 1 (2009): 97(10).

Haslanger, Sally Anne. Resisting Reality: Social Construction and Social Critique. New York: Oxford University Press, 2012. 
Hobbes, Thomas, and Crawford B. Macpherson. Leviathan. Repr. Penguin Classics. Harmondsworth: Penguin Books, 1988.

Hohmann, Jessie, and Joyce, Daniel eds. International Law's Objects. First Edition. Oxford, United Kingdom: Oxford University Press, 2018.

Hume, David, Stuart D. Warner, and Donald W. Livingston. Political Writings. Indianapolis: Hackett Pub. Co, 1994.

Hunt, Lynn. Inventing Human Rights: A History. 1st ed. New York: W.W. Norton \& Co, 2007.

Jarrell, Randall. Poetry and the Age. London: Faber, 1996.

Joas, Hans. The Sacredness of the Person: A New Genealogy of Human Rights. Washington, D.C: Georgetown University Press, 2013.

Johns, Fleur. The Non-Legal in International Law: Unruly Law. Cambridge: Cambridge University Press, 2012.

Kaminsky, Ilya. Deaf Republic: Poems. Minneapolis, Minnesota: Graywolf Press, 2019.

Kendall, Sara, and Sarah Nouwen. "Representational Practices at the International Criminal Court: The Gap between Juridified and Abstract Victimhood. (The Practices of the International Criminal Court)." Law and Contemporary Problems 76, no. 3-4 (2013): 235.

Khaitan, Tarunabh. "Dignity as an Expressive Norm: Neither Vacuous Nor a Panacea." Oxford Journal of Legal Studies 32, no. 1 (March 1, 2012): 119. doi:10.1093/ojls/gqr024.

Kumar, Vidya. "Revolutionaries.” In Concepts for International Law: Contributions to Disciplinary Thought, edited by Jean D'Aspremont and Sahib Singh. Cheltenham, UK: Edward Elgar Publishing, 2019.

Larkin, Philip, and Archie Burnett. The Complete Poems. 1. American paperback ed. New York: Farrar, Straus and Giroux, 2013.

Lebow, Richard Ned. A Cultural Theory of International Relations, 2009. 
Leighton, Stephen R. “A New View of Emotion.” American Philosophical Quarterly 22, no. 2 (1985): 133-41.

Leighton, Stephen R., ed. Philosophy and the Emotions: A Reader. Peterborough, Ont.; Orchard Park, NY: Broadview Press, 2003.

Lorca, Rocio. "Punishing the Poor and the Limits of Legality." Law, Culture and the Humanities, July 23, 2018, 174387211878998. doi:10.1177/1743872118789985.

Lorde, Audre. Sister Outsider: Essays and Speeches. Berkeley, Calif: Crossing Press, c2007, n.d.

Maroney, Terry. “Angry Judges.” Vanderbilt Law Review 65, no. 5 (2012): 1205-86.

-_- "Law and Emotion: A Proposed Taxonomy of an Emerging Field." Law and Human Behavior 30, no. 2 (2006): 119-42. doi:10.1007/s10979-006-9029-9.

Megiddo, Tamar. "The Domestic Standing of International Law: A Non-State Account." Columbia Journal of Transnational Law 57 (2019): 494.

Mishra, Pankaj. Age of Anger: A History of the Present. First American edition. New York: Farrar, Straus and Giroux, 2017.

Modirzadeh, Naz K. "Cut These Words: Passion and International Law of War Scholarship.” Harvard International Law Journal 61, no. 1 (2020). doi:10.2139/ssrn.3485822.

Murdoch, Iris. “Against Dryness: A Polemical Sketch.” Encounter, 1961.

-_- Metaphysics as a Guide to Morals. 1st American ed. New York: Allan Lane, The Penguin Press, 1993.

Nagel, Thomas. Concealment and Exposure: And Other Essays. Oxford; New York: Oxford University Press, 2002. 
Nietzsche, Friedrich Wilhelm. On the Advantage and Disadvantage of History for Life. Indianapolis: Hackett Pub. Co, 1980.

Norrie, Alan. "Animals Who Think and Love: Law, Identification and the Moral Psychology of Guilt." Criminal Law and Philosophy 13, no. 3 (September 2019): 515-44. doi:10.1007/s11572-018-9483-8.

Norrie, Alan W. Law and the Beautiful Soul. London; Portland, Or.: Portland, Or: GlassHouse; Published in the United States by Cavendish Pub, 2005.

Nunez, Sigrid. "Sex and Sincerity." The New York Review of Books, June 11, 2020.

Nussbaum, Martha Craven. Hiding from Humanity: Disgust, Shame, and the Law. Princeton, N.J: Princeton University Press, 2004.

- - Upheavals of Thought: The Intelligence of Emotions. 8th pr. Cambridge: Cambridge Univ. Press, 2008.

Pahuja, Sundhya. Decolonising International Law: Development, Economic Growth and the Politics of Universality. Cambridge: Cambridge University Press, 2011. doi:10.1017/CBO9781139048200.

Prinz, Jesse. "The Emotional Basis of Moral Judgments.” Philosophical Explorations 9, no. 1 (March 2006): 29-43.

—_- The Emotional Construction of Morals. Oxford University Press, 2009.

Purdy, Jedediah. "Laundered Violence: Law and Protest in Durham." N+1, August 23, 2017. https://nplusonemag.com/online-only/onlineonly/laundered-violence/.

Robinson, Jenefer. Deeper than Reason: Emotion and Its Role in Literature, Music, and Art. Oxford: New York: Clarendon Press; Oxford University Press, 2005.

Sanger, Carol. "Legislating with Affect: Emotion and Legislative Law Making." Nomos 53 (2013): 38-76. 
Sartre, Jean-Paul. Sketch for a Theory of the Emotions. Reprint. Routledge Classics. London: Routledge, 2006.

Schnädelbach, Sandra. "The Voice Is the Message: Emotional Practices and Court Rhetoric in Early Twentieth Century Germany.” Oñati SocioLegal Series 9, no. 9(5) (December 1, 2019): 616-35. doi:10.35295/osls.iisl/0000-0000-0000-1030.

Schwöbel-Patel, Christine. Marketing Global Justice: The Political Economy of International Criminal Law. Cambridge Studies in International and Comparative Law 152. Cambridge: Cambridge University Press, 2021.

Sebastian, Mihail, and Seán Ó Ceallaigh. For Two Thousand Years. Penguin Modern Classics. UK: Penguin Books, 2016.

Simpson, Gerry. "The Sentimental Life of International Law." London Review of International Law 3, no. 1 (March 1, 2015): 3-29. doi:10.1093/lril/lru013.

- - The Sentimental Life of International Law: Literature, Language and Longing. Oxford: Oxford University Press, 2021.

Slaughter, Joseph R. Human Rights, Inc. Fordham University Press, 2007. doi:10.5422/fordham/9780823228171.001.0001.

Solomon, Robert C. Not Passion's Slave: Emotions and Choice. The Passionate Life. Oxford; New York: Oxford University Press, 2003.

- - The Passions: Emotions and the Meaning of Life. Indianapolis: Hackett Pub. Co, 1993.

Srinivasan, Amia. “The Aptness of Anger." Journal of Political Philosophy 26, no. 2 (June 2018): 123-44. doi:10.1111/jopp.12130.

Stevenson, Charles Leslie. "The Emotive Meaning of Ethical Terms.” Mind XLVI, no. 181 (1937): 14-31. doi:10.1093/mind/XLVI.181.14.

Stina Bergman Blix, Kathy Mack, Terry Maroney, and Sharyn Roach Anleu. "Introducing an Interdisciplinary Frontier to Judging, Emotion and 
Emotion Work.” Oñati Socio-Legal Series 9, no. 5 (2019): 548-56. doi:10.35295/osls.iisl/0000-0000-0000-1095.

Stocker, Michael, and Elizabeth Hegeman. Valuing Emotions. Cambridge Studies in Philosophy. Cambridge [England]; New York: Cambridge University Press, 1996.

Tallgren, Immi, and Thomas Skouteris, eds. The New Histories of International Criminal Law: Retrials. History and Theory of International Law. Oxford, United Kingdom: Oxford University Press, 2019.

Temple, Kathryn. Loving Justice: Legal Emotions in William Blackstone's England. New York: New York University Press, 2019.

Von Bernstorff, Jochen. The Battle for International Law: South-North Perspectives on the Decolonization Era. New York, NY: Oxford University Press, 2019.

"W. H. Auden, The Art of Poetry No. 17." The Paris Review, Spring 1974. https://www.theparisreview.org/interviews/3970/the-art-of-poetryno-17-w-h-auden.

Waldron, Jeremy. The Harm in Hate Speech. The Oliver Wendell Holmes Lectures, 2009. Cambridge, Mass: Harvard University Press, 2012.

Wall, Illan rua. "The Ordinary Affects of Law." Law, Culture and the Humanities, November 16, 2019, 174387211988650. doi:10.1177/1743872119886509.

West, Robin. "Love, Rage and Legal Theory." Yale Journal of Law and Feminism 1, no. 1 (1989): 101-10.

White, Emily Kidd. Emotions in Legal Reasoning. Oxford Legal Philosophy. Oxford University Press, forthcoming.

-__. "On Emotions and the Politics of Attention in Judicial Reasoning." In Virtue, Emotion and Imagination in Legal Reasoning, edited by Amalia Amaya and Maksymilian Del Mar. London; UK: Hart Publishing, 2020. 
-__. "Till Human Voices Wake Us." Journal of Law, Religion and State 3 (2014): 201.

Williams, Bernard Arthur Owen. Shame and Necessity. New ed. Sather Classical Lectures 57. Berkeley, Calif.: University of California Press, 2008.

Williams, Patricia J. "The Raw and the Half-Cooked." in The Humanities and Public Life, edited by Peter Brooks and Hilary Jewett, First edition. New York: Fordham University Press, 2014. 